\title{
Menentukan Objek Wisata di Bali Masa Pandemi COVID-19 dengan Metode Weighted Product yang Dimodifikasi
}

\author{
I Nyoman Sweta ${ }^{\mathrm{a} 1}$, I Made Sukarsa ${ }^{\mathrm{b} 2}$ \\ ${ }^{a}$ Integrasi Pengolahan dan Diseminasi Statistik, Badan Pusat Statstik Provinsi Bali \\ Jl. Raya Puputan (Renon) No 1, Denpasar-Bali 80226 \\ ${ }^{1}$ sweta@bps.go.id \\ ${ }^{b}$ Universitas Udayana \\ Jl. Raya Kampus Udayana, Jimbaran, Kec. Kuta Sel., Kabupaten Badung, Bali 80361 \\ ${ }^{2}$ sukarsalunud.ac.id
}

\begin{abstract}
Abstrak
Pandemi COVID-19 memberikan dampak yang luar biasa terhadap perekonomian global termasuk Indonesia khususnya pada sektor industri pariwisata, perdagangan dan investasi. Apalagi Bali yang sangat bergantung dari sektor pariwisata. Pada masa new normal, pemangku kepentingan mulai harus menyiapkan strategi untuk menentukan kembali beroperasionalnya sektor unggulan ini tanpa mengabaikan aspek kesehatan. Alat bantu diperlukan untuk bahan pertimbangan dalam mengambil kebijakan nantinya. Agar keputusan yang dihasilkan obyektif dan cepat pada masa Pandemi, diperlukan sebuah alat berupa sistem yang dapat membantu dalam pengambilan suatu keputusan yang tepat. Multi Attribute Decision Making (MADM) merupakan suatu cara pengambilan keputusan dalam menentukan alternatif terbaik dari beberapa alternatif yang tersedia berdasarkan beberapa kriteria yang ada. Beberapa metode untuk menyelesaikan MADM seperti Simple Additive Weighting Method dan Weighted Product. Hasil perangkingan dengan Weighted Product lebih teliti, efisien dan sederhana. Untuk mengantisipasi kebijakan masa Pandemi, diperlukan melakukan modifikasi terhadap metode Weighted Product. Berdasarkan hal tersebut, maka dilakukan penelitian dengan judul "Menentukan Objek Wisata di Bali Masa Pandemi COVID-19 dengan Metode Weighted Productyang Dimodifikasi". Sistem yang dikembangkan sudah diuji dengan pengujian black box untuk memastikan fungsionalitas sistem dan pengujian hasil perhitungan metode untuk mengukur akurasi. Penelitian ini bisa menjadi salah satu alat bantu bagi pemangku kepentingan di Provinsi Bali untuk menentukan obyek wisata yang layak dikunjungi pada masa Pandemi COVID-19.
\end{abstract}

Kata kunci: Weighted Product, Pandemi COVID-19, Pariwsata Bali, New Normal

\section{Determining Tourism Objects in Bali during the COVID-19 Pandemic with a Modified Weighted Product Method}

\begin{abstract}
The COVID-19 pandemic has had a tremendous impact on the global economy including Indonesia, especially in the tourism, trade and investment industry sectors. Moreover, Bali is very dependent on the tourism sector. During the new normal period, stakeholders began to prepare strategies to determine the return to operation of this leading sector without neglecting the health aspect. Tools are needed for consideration in making policies later. In order for the resulting decisions to be objective and fast during the Pandemic, we need a tool in the form of a system that can assist in making an appropriate decision. Multi Attribute Decision Making (MADM) is a way of making decisions in determining the best alternative from several available alternatives based on several existing criteria. Several methods for solving MADM such as Simple Additive Weighting Method and Weighted Product. The ranking results with Weighted Products are more accurate, efficient and simple. To anticipate the Pandemic era policy, it is necessary to make modifications to the Weighted Product method. Based on this, a research was carried out with the title "Determining Tourism Objects in Bali during the COVID-19 Pandemic with a Modified Weighted Product Method". The system developed has been tested with black box testing to ensure system functionality and testing the results of calculation methods to measure accuracy. This research can be a tool for stakeholders in the Province of Bali to determine tourism objects worth visiting during the COVID-19 pandemic.
\end{abstract}

Keywords: Weighted Product, Pandemic COVID-19, Bali Tourism, New Normal 


\section{Pendahuluan}

Penelitian ini bertujuan untuk memberikan solusi berupa Sistem Pendukung Keputusan (SPK) yang memberikan rekomendasi obyek wisata layak dibuka pada masa pandemi COVID-19 dengan metode Weighted Product yang dimodifikasi kepada pemangku kepentingan di provinsi Bali. Penelitian ini diambil untuk mendukung upaya pemerintah dalam pemulihan pariwisata [1].

Pandemi COVID-19 membawa dampak yang cukup besar bagi perekonomian global termasuk Indonesia khususnya pada sektor industri pariwisata, perdagangan dan investasi [2]. Demikian juga halnya dengan Bali yang sangat bergantung dari sektor pariwisata. BPS Provinsi Bali melaporkan bahwa perekonomian Bali secara (y-on-y) tercatat mengalami kontraksi sedalam -12,28 persen pada triwulan III tahun 2020 ketergantungan pada sektor sektor pariwisata sangat rentan terhadap berbagai fenomena global seperti isu kolera, perang, dan terkini pandemi COVID-19. Dampak dari peristiwa tersebut sangat terasa dan langsung mempengaruhi kondisi perekonomian di wilayah Bali [3].

Dampak pandemi COVID-19 ini tentu saja sangat dirasakan bagi tenaga kerja yang bekerja di sektor pariwisata dan sektor terkait lainnya. Sebanyak 71.313 pekerja sektor formal mengalami pemutusan hubungan kerja (PHK) [4]. Survei Angkatan Kerja Nasional 2020, mengungkap bahwa sekitar 24,69 persen penduduk usia kerja di Bali terdampak gejolak pandemi COVID-19. Diperkirakan 98,18 ribu orang menjadi pengangguran akibat situasi ini [5].

Sampai saat ini belum dapat dipastikan kapan pandemi ini akan berlalu. Demikian pula halnya dengan vaksin COVID-19 belum dapat tersedia dalam waktu dekat. Sementara ekonomi terap harus diselamatkan. Dengan berbagai pertimbangan tersebut, pemerintah mengambil kebijakan new normal tentunya tanpa mengabaikan apsek kesehatan [6].

Sejatinya pemerintah telah berupaya melakukan langkah-langkah untuk menyelamatkan dan meningkatkan laju ekonomi dalam sektor pariwisata. New normal tourism pada beberapa tempat telah dilakukan, dengan tetap menerapkan protokol kesehatan. Salah satu dari new normal tourism adalah Bali [7]. Pemerintah Bali sangat serius menyongsong ini dengan mengeluarkan Surat Edaran (SE) Gubernur Bali Nomor 3355 Tahun 2020 tentang Penerapan Tatanan Kehidupan Era Baru [8].

Dalam upaya kebijakan new normal khususnya sektor pariwisata, maka pemangku kepentingan harus sudah menyiapkan destinasi obyek wisata yang siap dioperasikan. Kajian komprehensif mutlak diperlukan mengingat ini menyangkut kepentingan banyak hal. Salah satunya adalah mengunakan alat bantu berupa SPK.

Berangkat dari masalah tersebut, penulis membuat penelitian SPK untuk membantu pemangku kepentingan dalam menentukan obyek wisata yang layak dikunjungi pada masa pandemi COVID-19. Sistem ini menggunakan metode Weighted Product yang dimodifikasi. Menggunakan framework Laravel dan database MySql.

Penerapan metode Weighted Product sudah banyak ditemukan dalam berbagai bidang penelitian yang mengunakan multi kriteria dimana sektor pariwisata termasuk di dalamnya. Seperti penelitian tentang perbandingan metode untuk menentukan e-commerce terbaik di Indonesia [9]. Penelitian berikutnya terkait dengan rekomendasi penempatan Praktek Kerja Industri [10]. Selanjutnya penelitian untuk memilih destinasi wisata dan kuliner di Malang [11].

Metode Weighted Product dipilih karena hasil perangkingan lebih teliti [12]. Metode ini juga Efisien karena waktu yang diperlukan untuk melakukan perhitung lebih singkat [13].

\section{METODE PENELITIAN}

\section{A. Metode Pengembangan Sistem}

Metode penelitian SPK ini menggunakan model waterfall, merupakan model pengembangan sistem yang sistematik dan runut [14]. Adapun tahapannya dapat dilihat pada Gambar 1.

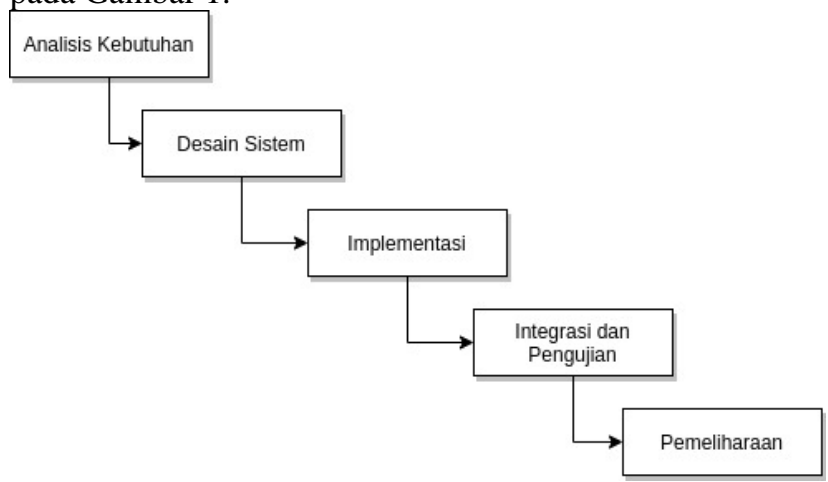

Gambar 1. Tahapan metode waterfall

Penjelasannya dari tahapan proses metode waterfall adalah sebagai berikut [15]:

Pada tahap analisis kebutuhan beberapa kriteria yang dibutuhkan dikumpulkan untuk menentukan kelayakan daerah obyek wisata untuk dikunjungi. Kriteria tidak dikumpulkan semua, karena dengan sistem yang dibuat kriteria untuk mendukung keputusan bisa ditambahkan secara dinamis.

Berikutnya adalah tahapan pemilihan metode untuk membuat SPK ini. Dalam penelitian ini memilih metode Weighted Product yang dimodifikasi. Modifikasi dimaksudkan untuk menambah tahapan penentuan keputusan setelah perhitungan Weighted Product. Untuk membantu mendapatkan gambaran sistem yang dikembangkan, maka dibuatkan pemodelan berupa diagram use case.

Pada tahap implementasi dilakukan penerjemahan SPK ke dalam Laravel salah satu framework pada bahasa pemrograman PHP. Laravel digunakan untuk mengembangkan sebuah aplikasi dengan konsep model view controller (MVC), menyediakan sintak yang ekspresif, jelas serta menghemat waktu [16].

Seluruh unit yang dibangun kemudian diintegrasikan menjadi satu kesatuan pada sebuah sistem dan dilakukan pengujian. Tujuan dari pengujian ini adalah menguji apakah sistem yang sudah dibuat sesuai dengan kriteriakriteria yang diinginkan.

Tahap terakhir dalam metode waterfall adalah melakukan pemeliharaan dari sistem yang berjalan. Pada 
tahap pemeliharaan, lesalahan yang tidak ditemukan pada langkah sebelumnya bisa diperbaiki pada tahap ini.

\section{B. Metode Weighted Product}

Metode Weighted Product merupakan salah satu metode untuk menyelesaikan Multi Attribute Decision Making (MADM). Teknik yang digunakan dalam Weighted Product melakukan perkalian untuk menghubungkan rating atribut, dimana rating setiap atribut harus dipangkatkan terlebih dahulu dengan atribut bobot yang bersangkutan [17].

Proses perhitungan dengan metode Weighted Product terdiri dari beberapa langkah sebagai berikut:

Langkah pertama adalah menentukan nilai bobot dari setiap kriteria (W). Pada perhitungan ini nilai $\mathrm{W}$ akan berada pada rentang dari 0 sampai dengan 1 . Dimana total nilai $\mathrm{W}$ adalah 1 . Untuk mendapatkan nilai normalisasi $\mathrm{Wj}$ dengan cara mengalikan atribut yang menguntungkan (benefit) dengan 1, sementara yang atribut bernilai biaya (cost) dikalikan dengan -1. Ada perhitungannya adalah dengan menggunakan rumus (1).

$W_{j}=\frac{W_{j}}{\sum W_{j}}$

Dengan $\mathrm{W}=$ bobot kriteria dan $\mathrm{j}=\mathrm{kriteria}$.

Berikutnya adalah langkah mencari hasil normalisasi dari setiap alternatif. Caranya dengan mengalikan seluruh kriteria bagi sebuah alternatif dengan bobot yang sudah dinormalisasi sebagai pangkat. Si adalah hasil normalisasi keputusan pada alternatif ke-i, Xij adalah rating alternatif per attribut, i adalah alternatif, $\mathrm{j}$ adalah atribut. Adapun perhitungannya adalah dengan rumus (2).

$S_{i}=\prod_{j=1}^{n} X_{i j}^{W_{j}}$

Dengan $S=$ Preferensi alternatif dianologikan sebagai vektor, $\mathrm{X}=$ nilai kriteria, $\mathrm{i}=$ alternatif , dan $\mathrm{n}=$ banyaknya kriteria.

Terakhir adalah mencari hasil preferensi setiap alternatif (V). Setelah nilai V didapatkan, maka diurutkan dari nilai terbesar. Nilai $\mathrm{V}$ terbesar merupakan alternatif terbaik. Nilai V didapatkan dengan menggunakan rumus (3).

$V_{i}=\frac{\prod_{j=1}^{n} X_{i j}^{W_{j}}}{\prod_{j=1}^{n} X_{i j} * W_{j}}$

Dengan $V=$ preferensi setiap alternatif.

\section{HASIL DAN PEMBAHASAN}

Modifikasi pada metode ini dimaksudkan untuk menambah tahapan penentuan keputusan yang tidak diperhitungkan setelah proses perhitungan Weighted Product. Pada perhitungan Weighted Product akan mendapatkan hasil berupa urutan terbesar dari sejumlah alternatif yang dalam hal ini adalah obyek wisata. Modifikasi metode dilakukan dengan menambahkan atribut kategori untuk mengelompokkan obyek wisata. Pada masa pandemi COVID-19 ini, otoritas tertinggi (pemerintah pusat) bisa saja mengeluarkan keputusan atau kebijaksanan yang bersifat mendadak terkait ijin operasional dunia usaha. Kebijakan tersebut misalnya mengatur kategori obyek wisata yang boleh dan tidak boleh dibuka pada masa pandemi. Jadi jika obyek wisata yang sudah disiapkan mendapatkan nilai tinggi sesuai metode Weighted Product, tetapi tidak termasuk kategori yang diijinkan beroperasional, maka tetap harus dieliminasi. Adapun gambaran dari modifikasi metode ini adalah seperti Gambar 2.

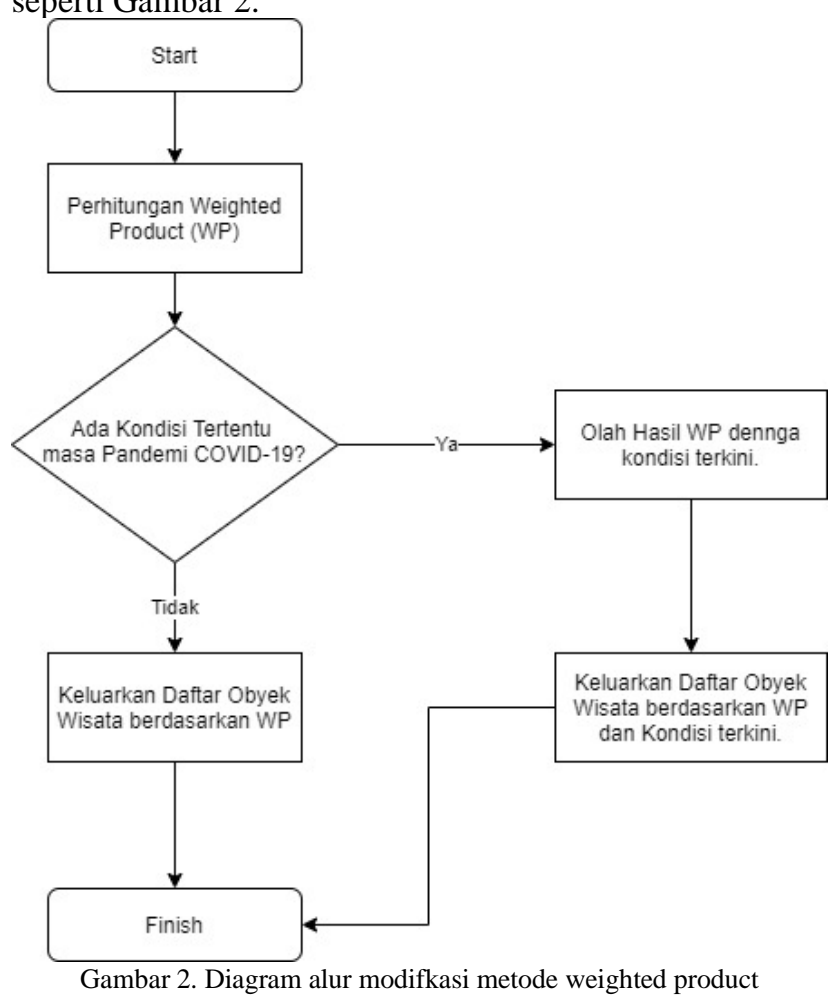

\section{A. Perhitungan Weighted Product}

Kriteria yang dijadikan pertimbangan kelayakan obyek wisata untuk dikunjungi ditentukan oleh pemangku kepentingan berdasarkan berbagai pertimbangan. Kriteria bersifat dinamis dimana bisa ditambahkan atau dikurangi sesuai dengan kebutuhan pada penerapan suatu kasus. Beberapa kriteria yang bisa dijadikan pertimbangan seperti ditunjukkan pada Tabel I.

TABEL I

DAFTAR KRITERIA

\begin{tabular}{|c|l|c|c|}
\hline Kode & Kriteria & Jenis & Bobot \\
\hline C1 & Penerapan protokol kesehatan COVID-19 & Benefit & 5 \\
\hline C2 & $\begin{array}{l}\text { Penerapan Protokol Kesehatan COVID-19 } \\
\text { masyarakat sekitar Obyek Wisata }\end{array}$ & Benefit & 4 \\
\hline C3 & Zona Wilayah (Tinggi=Merah) & Cost & 5 \\
\hline C4 & $\begin{array}{l}\text { Akomodasi dan Transportasi ke Obyek } \\
\text { Wisata }\end{array}$ & Benefit & 3 \\
\hline C5 & Sarana dan Prasarana & Benefit & 5 \\
\hline
\end{tabular}

Dari Tabel I tersebut kemudian dilakukan perhitungan bobot, dan hasilnya adalah sebagai berikut:

Untuk kriteria yang termasuk biaya, maka $\mathrm{Wj}$ ternomaliasi dikalikan -1 , sedangan yang menguntungkan dikalikan 1 atau tetap, seperti terlihat pada Tabel II. 
TABEL II

NORMALISASI BOBOT

\begin{tabular}{|c|c|c|c|}
\hline Kriteria & $\mathbf{W j}$ & Jenis & $\mathbf{W j}$ \\
\hline $\mathrm{C} 1$ & 0.23 & Benefit & 0.23 \\
\hline $\mathrm{C} 2$ & 0.18 & Benefit & 0.18 \\
\hline $\mathrm{C} 3$ & 0.23 & Cost & -0.23 \\
\hline $\mathrm{C} 4$ & 0.14 & Benefit & 0.14 \\
\hline $\mathrm{C} 5$ & 0.23 & Benefit & 0.23 \\
\hline
\end{tabular}

Menentukan sejumlah alternatif. Pada penelitian ini alternatifnya adalah daerah tujuan wisata yang dipersiapkan beroperasi pada masa new normal tourism seperti pada Tabel III.

TABEL III

DAFTAR ALTERNATIF

\begin{tabular}{|l|l|l|c|}
\hline Kode & Alternatif & \multicolumn{1}{|c|}{ Lokasi } & Kategori \\
\hline OW1 & Obyek Wisata 1 & Badung & A \\
\hline OW2 & Obyek Wisata 2 & Denpasar & B \\
\hline OW3 & Obyek Wisata 3 & Gianyar & C \\
\hline OW4 & Obyek Wisata 4 & Bangli & B \\
\hline OW5 & Obyek Wisata 5 & Tabanan & A \\
\hline
\end{tabular}

Pada langkah ini kita mengisikan nilai kriteria dari setiap alternatif seperti pada Tabel IV.

TABEL IV

MENGISI NILAI KRITERIA

\begin{tabular}{|c|c|c|c|c|c|}
\hline \multirow{2}{*}{ Alternatif } & \multicolumn{5}{|c|}{ Kriteria } \\
\cline { 2 - 6 } & C1 & C2 & C3 & C4 & C5 \\
\hline OW1 & 5 & 5 & 2 & 2 & 5 \\
\hline OW2 & 5 & 5 & 3 & 5 & 5 \\
\hline OW3 & 4 & 3 & 3 & 5 & 5 \\
\hline OW4 & 3 & 5 & 4 & 4 & 5 \\
\hline OW5 & 5 & 3 & 3 & 5 & 5 \\
\hline
\end{tabular}

Menghitung Si dilakukan setelah bobot normalisasi didapatkan. Adapun perhitungannya adalah seperti pada Tabel V.

TABEL V

MENGHITUNG PREFERENSI

\begin{tabular}{|c|c|c|c|c|c|c|}
\hline Alternatif & $\mathbf{C 1}^{\wedge} \mathbf{W} \mathbf{j}$ & $\mathbf{C 2}^{\wedge} \mathbf{W} \mathbf{j}$ & $\mathbf{C} 3^{\wedge} \mathbf{W j}$ & $\mathbf{C 4}{ }^{\wedge} \mathbf{W j}$ & $\mathbf{C 5}^{\wedge} \mathbf{W} \mathbf{j}$ & $\mathbf{S i}$ \\
\hline OW1 & 1.44 & 1.34 & 0.85 & 1.10 & 1.44 & 2.61 \\
\hline OW2 & 1.44 & 1.34 & 0.78 & 1.25 & 1.44 & 2.70 \\
\hline OW3 & 1.37 & 1.22 & 0.78 & 1.25 & 1.44 & 2.34 \\
\hline OW4 & 1.28 & 1.34 & 0.73 & 1.21 & 1.44 & 2.19 \\
\hline OW5 & 1.44 & 1.22 & 0.78 & 1.25 & 1.44 & 2.46 \\
\hline
\end{tabular}

Menghitung nilai vektor dari setiap preferensi (Vi) adalah dengan membagis setiap preferensi dengan jumlah seluruh preferensi. Sehingga hasilnya dapat dilihat pada Tabel VI.

TABEL VI

MENGHITUNG NILAI VEKTOR

\begin{tabular}{|c|c|c|}
\hline Alternatif & Nama Alternatif & Vi \\
\hline OW1 & Obyek Wisata 1 & 0.21 \\
\hline OW2 & Obyek Wisata 2 & 0.22 \\
\hline OW3 & Obyek Wisata 3 & 0.19 \\
\hline OW4 & Obyek Wisata 4 & 0.18 \\
\hline OW5 & Obyek Wisata 5 & 0.20 \\
\hline
\end{tabular}

Setelah hasil perhitungan vektor didapatkan, langkah selanjutnya adalah melakukan perangkingan dengan mengurutkan dari nilai terbesar. Adapun hasil dari perangkingan hasil metode Weighted Product dapat dilihat pada Tabel VII.

TABEL VII

MENENTUKAN PERINGKAT

\begin{tabular}{|c|c|c|c|c|}
\hline Peringkat & Alternatif & Nama Alternatif & Kategori & Vi \\
\hline 1 & OW2 & Obyek Wisata 2 & B & 0.22 \\
\hline 2 & OW1 & Obyek Wisata 1 & A & 0.21 \\
\hline 3 & OW5 & Obyek Wisata 5 & A & 0.20 \\
\hline 4 & OW3 & Obyek Wisata 3 & C & 0.19 \\
\hline 5 & OW4 & Obyek Wisata 4 & B & 0.18 \\
\hline
\end{tabular}

\section{B. Modifikasi}

Modifikasi metode ini dilakukan dengan menambahkan atribut kategori di alternatif. Atribut ini berfungsi untuk mengelompokan alternatif. Dimana hasil pengelompokkan itu menjadi penentu akhir boleh tidaknya alternatif pilihan beroperasi pada masa Pandemi. Pada langkah ini kategori obyek wisata dilakukan pemutakhiran sesuai kebijakan terkini dari otoritas yang berwenang. Adapun hasilnya dapat dilihat pada Tabel VIII.

TABEL VII

MENENTUKAN KATEGOR

\begin{tabular}{|c|l|c|}
\hline Kode & Nama Kategori & Ijin Operasi \\
\hline A & Kelompok Obyek Wisata A & Y \\
\hline B & Kelompok Obyek Wisata B & N \\
\hline C & Kelompok Obyek Wisata C & Y \\
\hline D & Kelompok Obyek Wisata D & Y \\
\hline
\end{tabular}

Pada contoh Tabel 8, kategori yang tidak layak beroperasi adalah kategori B. Maka dilakukan proses eliminasi terhadap alternatif yang termasuk kategori B seperti pada Tabel IX.

TABEL VIX

ELIMINASI ALTERNATIF

\begin{tabular}{|c|c|c|c|c|}
\hline Peringkat & Nama Alternatif & Kategori & Vi & Final \\
\hline 1 & Obyek Wisata 2 & B & 0.22 & X \\
\hline 2 & Obyek Wisata 1 & A & 0.21 & 1 \\
\hline 3 & Obyek Wisata 5 & A & 0.2 & 2 \\
\hline 4 & Obyek Wisata 3 & C & 0.19 & 3 \\
\hline 5 & Obyek Wisata 4 & B & 0.18 & X \\
\hline
\end{tabular}

Setelah eliminasi dilakukan, maka akan didapatkan hasil akhir berupa perangkingan metode Weighted Product dengan mengeliminasi alternatif yang tidak diijinkan beroperasi. Sehingga hasil akhirnya adalah seperti pada Tabel X.

TABEL X

PERINGKat AKHIR SETElah ModifIKASI

\begin{tabular}{|c|c|c|c|c|}
\hline Peringkat & Nama Alternatif & Kategori & Vi & Final \\
\hline 1 & Obyek Wisata 1 & A & 0.21 & 1 \\
\hline 2 & Obyek Wisata 5 & A & 0.2 & 2 \\
\hline 3 & Obyek Wisata 3 & C & 0.19 & 3 \\
\hline
\end{tabular}

\section{Diagram Use Case}

Diagram use case dibuat untuk menganalisa kebutuhan dan mengetahui interaksi antara aktor dengan sistem. Aktor yang terlibat dalam sistem adalah Administrator, Operator dan Pemangku Kepentingan. Administrator bertugas untuk mengelola pengguna sistem. Operator bertugas untuk 
mengelola alternatif, kriteria dan melakukan perhitungan untuk memproleh daftar rangking alternatif. Sedangkan Pemangku Kepentingan melihat hasil perhitungan untuk dijadikan dalam menentukan keputusan operasional usaha obyek wisata. Hubungan antara aktor dan sistem dapat kita lihat pada Gambar 3.

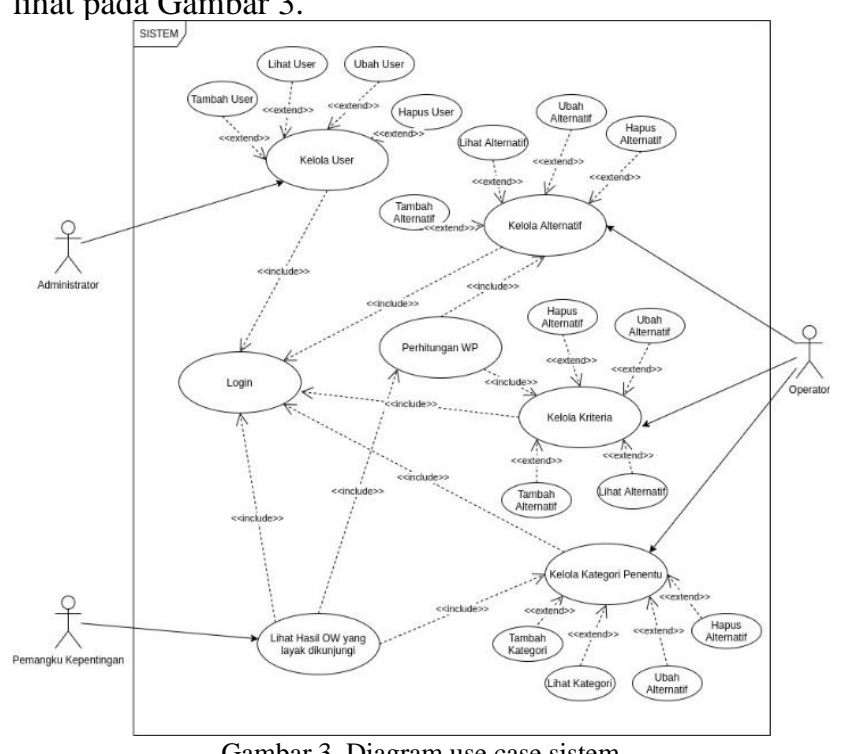

Gambar 3. Diagram use case sistem

\section{Implementasi}

Implementasi penelitian "Menentukan Objek Wisata di Bali Masa Pandemi COVID-19 dengan Metode Weighted Product yang Dimodifikasi” ini menggunakan framework Laravel dan database MySql. Sementara untuk kenyamanan pengguna dan user friendly, implementasi tampilan menggunakan framework Bootstrap [18].

Pada perhitungan dengan metode Weighted Product, kriteria yang diperlukan untuk mengambil keputusan bersifat dinamis. Kriteria dan bobot bisa diatur sesuai degan kebutuhan. Adapun tampilan untuk mengelola daftar kriteria dan bobot seperti pada Gambar 4 berikut. Data Kriteria

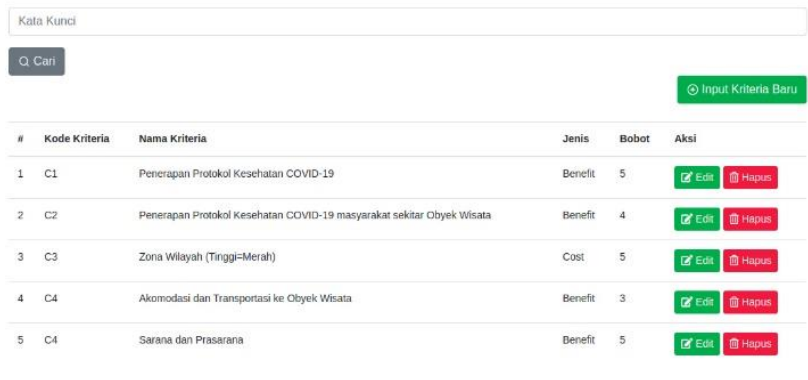

Gambar 4. Daftar kriteria

Berikutnya adalah mengelola alternatif yang dalam kasus penelitian ini adalah daerah obyek wisata. Pada halaman ini disedikan menu untuk menambah, melihat, mengubah dan menghapus alternatif sebagaimana terlihat pada Gambar 5.
Data Obyek Wisata (Alternatif)

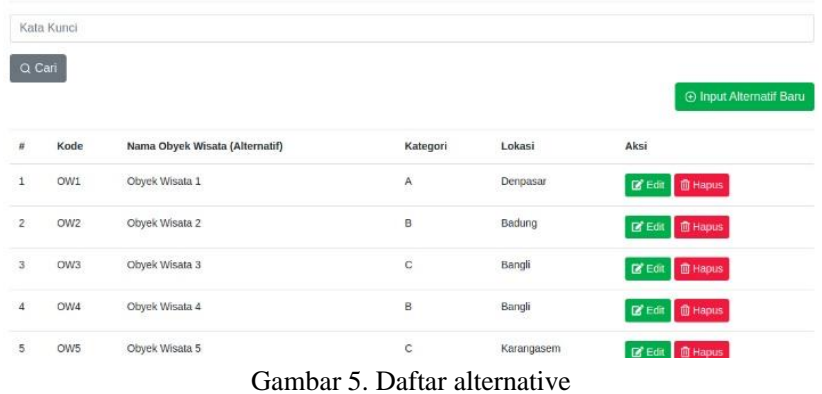

Untuk mengisi nilai kriteria dari setiap alternatif dapat dilihat seperti pada Gambar 6.

Edit Data Obyek Wisata (Alternatif)

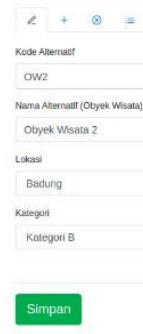

Gambar 6. Mengisi nilai kriteria

Hasil perhitungan bobot dan preferensi alternatif ditampilkan pada Gambar 7

Perhitungan Bobot Ternormalisasi

\begin{tabular}{|c|c|c|c|}
\hline Kiteria & $w_{1}$ & Jenis & 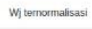 \\
\hline$c 1$ & 0.227 & Benentr & 0.227 \\
\hline$c 2$ & 0.182 & Beneer & 0.182 \\
\hline c3 & 0.227 & $\cos t$ & .0277 \\
\hline ca & 0.136 & Beneft & 0.136 \\
\hline$c 5$ & 0.227 & Beneftr & 0.227 \\
\hline
\end{tabular}

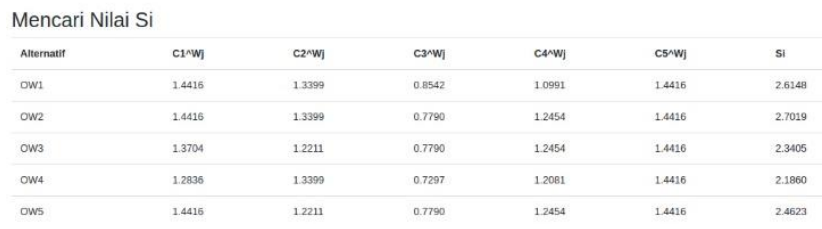

Gambar 7. Perhitungan bobo dan preferensi alternatif

Hasil akhir perhitungan dengan Weighted Product adalah berupa perangkingan dari setiap alternatif yang tersedia. Berikut ini adalah tampilan rangking dan grafik batang seperti pada Gambar 8.
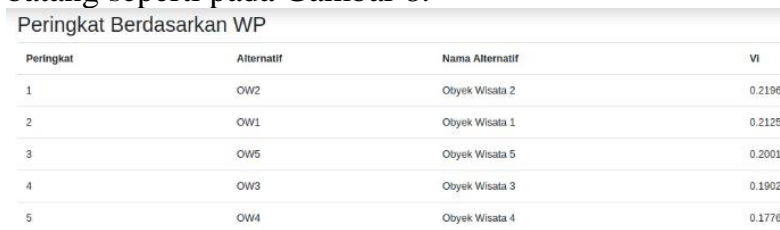

Rangking

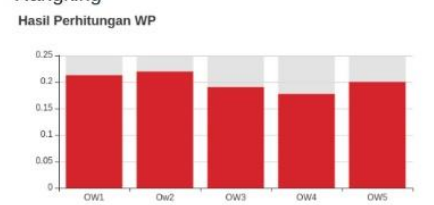

Gambar 8. Hasil perhitungan metode weighted product

Modifikasi pada metode Weighted Product pada penelitian ini adalah dengan menambahkan atribut kategori pada alternatif. Kategori ini untuk menentukan proses eliminasi alternatif. Ada kemungkinan alternatif yang hasil 
rangking perhitungan metode Weighted Product bagus, tapi tereliminasi oleh kategori alternatifnya. Proses eliminasi bisa dilihat pada Gambar 9.

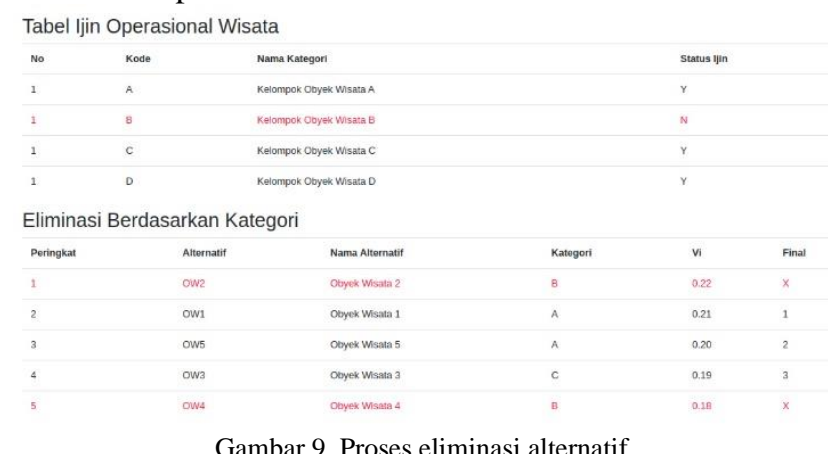

Hasil akhir dari penelitian ini adalah perangkingan alternatif terbaik dengan melewati proses perhitungan Weighted Product yang sudah dimodifikasi. Adapun tampilannya adalah seperti pada Gambar 10.

\begin{tabular}{|c|c|c|c|c|c|}
\hline Peringhat & Atternatt & Nama Altematit & Kategori & n & Final \\
\hline 1 & ow1 & Obyek Wrsata 1 & A & 0.21 & 1 \\
\hline 2 & ows & Cobyek Wistata 5 & A & 0.20 & 2 \\
\hline 3 & ows & Ophere wherata 3 & c & 0.19 & 3 \\
\hline
\end{tabular}

Gambar 10. Hasil perangkingan dengan metode weighted product yang dimodifkasi

\section{E. Pengujian Black Box}

Metode pengujian sistem menggunakan black box. Pengujuan dilakukan pada setiap tampilan [19]. Pengujian dilakukan untuk mengetahui apakah modul-modul yang digunakan pada sistem ini telah berfungsi dengan baik, seperti terlihat pada Tabel XI.

TABEL XI

PENGUJIAN BLACK BOX

\begin{tabular}{|l|l|l|l|l|}
\hline No & Skenario & $\begin{array}{l}\text { Hasil yang } \\
\text { diharapkan }\end{array}$ & Pengguna & Hasil \\
\hline 1 & $\begin{array}{l}\text { Pengujian modul } \\
\text { Kelola User }\end{array}$ & $\begin{array}{l}\text { Proses tambah, edit, } \\
\text { lihat, hapus data } \\
\text { pengguna berjalan. }\end{array}$ & Administrator & Sukses \\
\hline 2 & $\begin{array}{l}\text { Pengujian modul } \\
\text { Kelola Alternatif }\end{array}$ & $\begin{array}{l}\text { Proses tambah, edit, } \\
\text { lihat, hapus data } \\
\text { alternatif berjalan. }\end{array}$ & Operator & Sukses \\
\hline 3 & $\begin{array}{l}\text { Pengujian modul } \\
\text { Kelola Kriteria }\end{array}$ & $\begin{array}{l}\text { Proses tambah, edit, } \\
\text { lihat, hapus data } \\
\text { kriteria berjalan. }\end{array}$ & Operator & Sukses \\
\hline 5 & $\begin{array}{l}\text { Pengujian modul } \\
\text { Kelola Kategori }\end{array}$ & $\begin{array}{l}\text { Proses tambah, edit, } \\
\text { lihat, hapus data } \\
\text { kategori berjalan. }\end{array}$ & Operator & Sukses \\
\hline Proses Weight & $\begin{array}{l}\text { Sistem melakukan } \\
\text { proses perhitungan } \\
\text { Weight Product yang } \\
\text { dimodifikasi }\end{array}$ & Operator & Sukses \\
\hline 6 & $\begin{array}{l}\text { Pengujian } \\
\text { Laporan Weight } \\
\text { Product }\end{array}$ & $\begin{array}{l}\text { Sistem menampilkan } \\
\text { laporan perhitungan } \\
\text { Weight Product yang } \\
\text { dimodifikasi }\end{array}$ & $\begin{array}{l}\text { Pemangku } \\
\text { Kepentingan }\end{array}$ & Suskes \\
\hline
\end{tabular}

\section{F. Pengujian Hasil}

Berikutnya adalah pengujian hasil perhitungan metode yang digunakan. Pertama dilakukan pengujian metode Weighted Product dengan cara membandingkan perhitungan manual dengan alat bantu software libreoffice spreedsheet di sistem operasi Linux dengan perhitungan oleh sistem yang dikembangkan. Berikutnya dilanjutkan dengan perbandingan hasil proses eliminasi dengan metode yang sudah dimodifikasi. Hasil pengujiannya dapat dilihat pada Tabel XII.

TABEL XII

PENGUJIAN HASIL

\begin{tabular}{|c|l|c|}
\hline No & \multicolumn{1}{|c|}{ Item Yang diujikan } & $\begin{array}{l}\text { Perbandingan } \\
\text { perhitungan manual } \\
\text { dengan sistem }\end{array}$ \\
\hline 1 & Perhitungan Weight Product & Sama \\
\hline 2 & $\begin{array}{l}\text { Proses Modifikasi Metode Weight } \\
\text { Product }\end{array}$ & Sama \\
\hline
\end{tabular}

\section{KESIMPULAN}

Setelah dilakukannya perancangan, implementasi serta pengujian pada sistem pendukung keputusan ini, maka dapat diperoleh beberapa kesimpulan. Kesimpulan pertama, metode Weighted Product dilakukan untuk melakukan perangkingan dari sejumlah obyek wisata berdasarkan kriteria yang ditentukan. Kesimpulan kedua, modifikasi metode Weighted Product diperlukan untuk melakukan antisipasi terhadap kebijakan aturan yang lebih tinggi dalam struktur pemerintahan. Berikutnya semua modul dalam SPK ini sudah berfungsi dengan baik dan hasil perhitungan sama perhitungan manual. Terakhir SPK ini bisa menjadi salah satu alat bantu untuk membantu pemerintah daerah Provinsi Bali dalam menentukan obyek wisata yang layak dikunjungi pada masa pandemi COVID19.

Adapun saran yang dapat diberikan kepada penelitian lanjutan adalah dengan menambahkan lebih dari satu kategori pada setiap alternatif. Dengan demikian pengelompokkan alternatif menjadi lebih fleksibel.

\section{UCAPAN TERIMA KASIH}

Terima kasih kepada Bapak Endan Suwandana, Ibu Yulia Virantina, Bapak Novianto Budi Kurniawan, Bapak Utama Andri Arjita, atas masukkannya yang sangat berharga. Terima kasih pula kepada Bapak I Gede Heprin Prayasta, Ibu Putu Galuh Ika Safitri atas koreksi dan sarannya terhadap penelitian ini.

\section{DAFTAR PUSTAKA}

"Bali Siapkan Langkah Sambut Pariwisata New Normal," Media Indonesia, 2020. https://mediaindonesia.com/read/detail/314451-bali-siapkanlangkah-sambut-pariwisata-new-normal (accessed Jun. 11, 2020).

D. A. D. Nasution, E. Erlina, and I. Muda, "Dampak Pandemi COVID-19 terhadap Perekonomian Indonesia," J. Benefita, vol. 5, no. 2, p. 212, 2020, doi: 10.22216/jbe.v5i2.5313.

T. T. Mihaela Rus, Mihaela Luminița Sandu, "A new decade for social changes," Tech. Sci. J., vol. 6, no. 6, pp. 69-87, 2020.

"Anjloknya Sektor Pariwisata Bali, Puluhan Ribu NAKER Sektor Formal alami PHK," Bali Post, 2020. https://www.balipost.com/news/2020/10/05/150370/Anjloknya -Sektor-Pariwisata-Bali,Puluhan...html (accessed Nov. 06, 2020).

"Berita Resmi Statistik Keadaan Ketenagakerjaan Provinsi Bali No. 69/11/51/Th. XIV, 5 November 2020,” 2020. https://bali.bps.go.id/pressrelease/download.html?nrbvfeve $=\mathrm{Nz}$ E3NDE1\&sdfs=ldjfdifsdjkfahi\&twoadfnoarfeauf=MjAyMC0x MS0xMCAyMjoyMjoyOQ\%3D\%3D (accessed Nov. 10, 2020).

[6] Widayatun, "Menyongsong Era New Normal Dalam Situasi Pandemi Covid -19: Momentum Peningkatkan Peran Keluarga Sebagai Agen Perubahan," LIPI, 2020. 
https://kependudukan.lipi.go.id/id/berita/53-

mencatatcovid19/1007-menyongsong-era-new-normal-dalamsituasi-pandemi-covid-19-momentum-peningkatkan-peran-

keluarga-sebagai-agen-perubahan (accessed Nov. 06, 2020).

[7] A. Maharani and F. Mahalika, "New Normal Tourism Sebagai Pendukung Ketahanan Ekonomi Nasional Pada Masa Pandemi ( New Normal Tourism As a Support of National Economic Resistance in the Pandemic Period )," J. Kaji. LEMHANNAS RI, vol. 8, p. 14, 2020, [Online]. Available: http://jurnal.lemhannas.go.id/index.php/jkl/article/view/87.

[8] I. D. G. Kusuma, "Wacana Pariwisata Bali Dalam Pusaran Pandemi Covid-19," J. Ilm. Cakrawarti, vol. 3, no. 2, pp. 40-47, 2020, doi: 10.47532/jic.v3i2.199.

[9] G. Surya, P. Gede, and S. Cipta, "Komparasi Metode AHPSAW dan AHP-WP pada SPK Penentuan E-Commerce Terbaik di Indonesia Comparison of AHP-SAW and AHP-WP Methods on DSS to Determine the Best E-Commerce in Indonesia," vol. 08, no. 4, pp. 346-356, 2020, doi: 10.26418/justin.v8i4.42611.

[10] D. Winarso, F. Nurita, and S. Syahril, "Penerapan Metode Weigth Product Untuk Rekomendasi Penempatan Praktek Kerja Industri (Study Kasus: SMK Muhammadiyah 01 Pekanbaru),' J. RESTI (Rekayasa Sist. dan Teknol. Informasi), vol. 2, no. 2, pp. 566-571, 2018, doi: 10.29207/resti.v2i2.467.

[11] J. Fredricka, Y. D. Atma, and S. Pendukung, "Implementasi Metode Weighted Product Dalam," vol. 2, no. 1, pp. 1-6, 2018.

[12] I. Anggraeni, "Analisis Perbandingan Metode SAW Dan Weight Product pada Pemilihan Calon Ketua Badan Eksekutif Mahasiswa ( BEM ) Universitas Pakuan," J. Komput. Terap., vol. 3, no. 2, pp. 203-212, 2017.

[13] J. E. M, D. Andreswari, and K. Anggriani, "Pemilihan Jenis Kayu Untuk Mebel Dengan Metode Weighted Product ( Wp ) \& Technique for Order Preference By Similarity To Ideal Solution ( Topsis )," pp. 301-310, 2016.

[14] P. Roger S., Rekayasa Perangkat Lunak: Pendekatan Praktisi (Buku Dua). Yogyakarta: Andi, 2002.

[15] I. Sommerville, Software Engineering (9th Edition). USA Addison-Wesley, 2011.

[16] Y. Supardi and Sulaeman, Y. Supardi and Sulaeman, Semua Bisa Menjadi Programmer Laravel Basic. Jakarta: PT Elex Media Komputindo, 2019

[17] S. Kusumadewi, S. Hartati, and R. Wardoyo, Fuzzy MultiAtributeDecition Making (Fuzzy MADM). Yogyakarta: Graha Ilmu, 2006.

[18] M. F. Santoso, "Teknik Responsive Web Design Bootstrap 4 Serta Penerapannya Dalam Rancang Bangun Layout Web," J. Pilar Nusa Mandiri, vol. 15, no. 1, pp. 61-68, 2019, doi: 10.33480/pilar.v15i1.101.

[19] M. Sony and R. Sabaruddin, "Rancang Bangun Dashboard Smart System Manajemen RT / RW Design and Build a Smart RT-RW Management System Dashboard to Support Society 5. 0," vol. 8, no. 2, pp. 328-332, 2020, doi 10.26418/justin.v8i4.42586. 